\title{
The calcium sign of aortic arch dissection
}

\author{
Sheng-Hsiang Lin, ${ }^{1,2}$ Shih-Horng Huang, ${ }^{3}$ Wan-Hsiu Liao ${ }^{4}$
}

1 Department of Internal Medicine, New Taipei City Hospital, New Taipei, Taiwan ${ }^{2}$ Department of Respiratory Therapy, Fu-Jen Catholic University, New Taipei, Taiwan ${ }^{3}$ Department of Surgery, New Taipei City Hospital, New Taipei, Taiwan ${ }^{4}$ Department of Family Medicine, New Taipei City Hospital, New Taipei, Taiwan

\section{Correspondence to} Dr Sheng-Hsiang Lin, linsh01@gmail.com

\footnotetext{
To cite: Lin S-H, Huang SH, Liao W-H. BMJ Case Rep Published online: [please include Day Month Year doi:10.1136/bcr-2013200658
}

\section{DESCRIPTION}

A 62-year-old man, a case of hypertension, presented with severe and progressive upper back pain for 1 day. Physical examinations were unremarkable, except for a high blood pressure (178/ $102 \mathrm{~mm} \mathrm{Hg}$ ). The haemogram and biochemistry were within normal limits. Chest radiography showed cardiomegaly, mediastinal widening and the calcium sign at aortic arch (figure 1). ECG showed sinus tachycardia (106 bpm) and nonspecific ST-T wave changes. A sudden loss of consciousness followed and cardiopulmonary resuscitation was performed immediately for pulseless electrical activity. Chest ultrasound showed fluid accumulation in left pleural cavity and fresh blood was noticed with thoracentesis. A diagnosis of thoracic aortic dissection with rupture into the left pleural cavity was made. Unfortunately, the patient died after $2 \mathrm{~h}$ resuscitation.

The diagnosis of aortic dissection is usually prompted by the presence of acute chest pain and mediastinal/aortic widening on chest radiography. ${ }^{1}$ Nonetheless, the radiological findings of aortic dissection are usually non-specific and its diagnosis depends on a high index of suspicion. ${ }^{2}$ The calcium sign defined as the separation of the intimal calcification from the outer aortic soft tissue border by more than $10 \mathrm{~mm}$ is a specific chest radiographic finding of aortic dissection. ${ }^{2}$ Although it would be observed in about $14 \%$ of patients with descending aorta dissection, this finding would be rare in patients with aortic arch dissection. ${ }^{3}$

\section{Learning points}

- The majority of chest radiographic findings in aortic dissection are not specific.

- The calcium sign indicating the separation of the intimal calcification from the outer aortic soft tissue border by more than $10 \mathrm{~mm}$ is specific for the diagnosis of aortic dissection.

- The calcium sign would be far more frequently observed in patients with descending aorta dissection than in those with aortic arch dissection.

\section{Competing interests None.}

Patient consent Obtained.

Provenance and peer review Not commissioned; externally peer reviewed.

\section{REFERENCES}

1 von Kodolitsch Y, Schwartz AG, Nienaber CA. Clinical prediction of acute aortic dissection. Arch Intern Med 2000;160:2977-82.

2 Klompas M. Does this patient have an acute thoracic aortic dissection? JAMA 2002;287:2262-72.

3 Slater EE, DeSanctis RW. The clinical recognition of dissecting aortic aneurysm. Am J Med 1976;60:625-33.

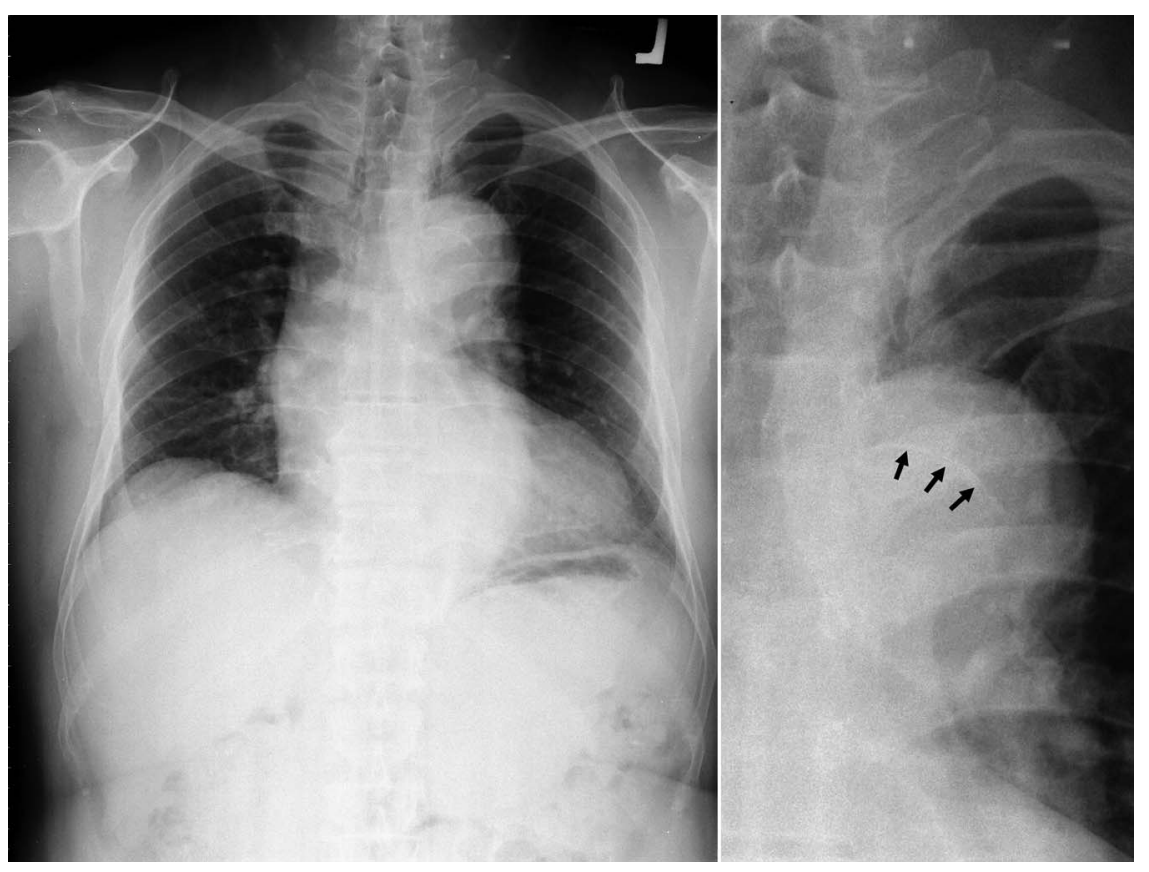

Figure 1 Chest radiography demonstrates cardiomegaly, mediastinal widening and the calcium sign at aortic arch (arrows). The right panel is a magnified area of aortic arch. 
Copyright 2013 BMJ Publishing Group. All rights reserved. For permission to reuse any of this content visit http://group.bmj.com/group/rights-licensing/permissions.

BMJ Case Report Fellows may re-use this article for personal use and teaching without any further permission.

Become a Fellow of BMJ Case Reports today and you can:

- Submit as many cases as you like

- Enjoy fast sympathetic peer review and rapid publication of accepted articles

- Access all the published articles

- Re-use any of the published material for personal use and teaching without further permission

For information on Institutional Fellowships contact consortiasales@bmjgroup.com

Visit casereports.bmj.com for more articles like this and to become a Fellow 